University of Nebraska - Lincoln

DigitalCommons@University of Nebraska - Lincoln

USDA National Wildlife Research Center - Staff Publications
U.S. Department of Agriculture: Animal and Plant Health Inspection Service

February 2006

\title{
Total Plasma Protein and Renesting by Greater Sage-Grouse
}

Michael A. Gregg

U.S. Fish and Wildlife Service, Sheldon-Hart Mountain National Wildlife Refuge Complex, Lakeview, OR

Mike R. Dunbar

U.S. Fish and Wildlife Service, Sheldon-Hart Mountain National Wildlife Refuge Complex

John A. Crawford

Oregon State University, Corvallis, OR

Michael D. Pope

Oregon State University, Corvallis, OR

Follow this and additional works at: https://digitalcommons.unl.edu/icwdm_usdanwrc

Part of the Environmental Sciences Commons

Gregg, Michael A.; Dunbar, Mike R.; Crawford, John A.; and Pope, Michael D., "Total Plasma Protein and Renesting by Greater Sage-Grouse" (2006). USDA National Wildlife Research Center - Staff Publications. 503.

https://digitalcommons.unl.edu/icwdm_usdanwrc/503

This Article is brought to you for free and open access by the U.S. Department of Agriculture: Animal and Plant Health Inspection Service at DigitalCommons@University of Nebraska - Lincoln. It has been accepted for inclusion in USDA National Wildlife Research Center - Staff Publications by an authorized administrator of DigitalCommons@University of Nebraska - Lincoln. 


\title{
Total Plasma Protein and Renesting by Greater Sage-Grouse
}

\author{
MICHAEL A. GREGG, ${ }^{1,2}$ U.S. Fish and Wildlife Service, Sheldon-Hart Mountain National Wildlife Refuge Complex, Lakeview, OR 97630, USA \\ MIKE R. DUNBAR, ${ }^{3}$ U.S. Fish and Wildlife Service, Sheldon-Hart Mountain National Wildlife Refuge Complex, Lakeview, OR 97630, USA \\ JOHN A. CRAWFORD, Department of Fisheries and Wildlife, Oregon State University, Corvallis, OR 97331, USA \\ MICHAEL D. POPE, Department of Fisheries and Wildlife, Oregon State University, Corvallis, OR 97331, USA
}

\begin{abstract}
Greater sage-grouse (Centrocercus urophasianus) population declines have been attributed to reduced productivity. Although renesting by sage-grouse may contribute significantly to annual productivity during some years, little information is available on this aspect of sage-grouse reproductive ecology. We investigated the relationship between total plasma protein, age of hen, time of first nest initiation, and time of first nest loss on occurrence of renesting. We captured, assigned age, extracted blood, and radiomarked prelaying, female sage-grouse on 4 study areas during 1999-2004. We monitored radiomarked females from mid-April through June to identify period of nest initiation (early, mid, or late), nest loss (early or late), and renesting activity. We only considered hens that were available to renest $(n=143)$ for analysis, and we censored those that nested successfully or died during their first nest attempt. Depredation and abandonment accounted for 85\% (122/143) and 15\% (21/143) of the unsuccessful first nests, respectively. The proportion of hens renesting was 34\% (48/143) across all study areas and years. Akaike's Information Criterion model selection indicated that occurrence of renesting varied by age, nest initiation period, nest loss period, and total plasma protein. The best model had low predictive power for any given hen $\left(r^{2}=0.296\right)$, but validation of the best model indicated that our predictor variables were important for distinguishing renesting status and likely explained substantial temporal and spatial variation in renesting rates. A greater proportion of adults than yearlings renested, and hens that nested early in the nesting season and lost nests early during incubation were the most likely to renest. Hens that renested had greater total plasma protein levels than non-renesting hens independent of age, nest initiation period, and nest loss period. Because sage-grouse depend on exogenous sources of protein for reproduction, land management practices that promote high-quality, prelaying hen habitat could increase dietary protein intake and sage-grouse renesting rates. (JOURNAL OF WILDLIFE MANAGEMENT 70(2):472-478; 2006)
\end{abstract}

\section{Key words}

age, blood chemistry, Centrocercus urophasianus, dietary protein, greater sage-grouse, maternal condition, nest initiation date, nest predation, nutrition, renesting, total plasma protein.

Greater sage-grouse populations have declined across their range since the 1950s, and declines have been linked to several factors, particularly reduced productivity (Crawford and Lutz 1985, Connelly and Braun 1997, Connelly et al. 2004). Considerable research has been conducted on factors that influence sage-grouse reproductive success including prelaying hen condition (Barnett and Crawford 1994), nest success (Wallestad and Pyrah 1974, Connelly et al. 1991, Gregg et al. 1994, Sveum et al. 1998a), and brood survival (Johnson and Boyce 1990, Drut et al. 1994a, Sveum et al. 1998b, Aldridge and Brigham 2001). Few investigations have focused on factors that influence renesting (Connelly et al. 1993, Schroeder 1997), although considerable variation of sagegrouse renesting rates has been reported from radiotelemetry studies. Renesting rates for sage-grouse have ranged from $87 \%$ in Washington (Schroeder 1997), 36\% in Alberta (Aldridge and Brigham 2001), $15 \%$ in Idaho (Connelly et al. 1993), and 6\% in Oregon (Hanf et al. 1994). Understanding factors that influence renesting rates is important for sage-grouse management because renesting can contribute significantly to annual recruitment of young during some years (Schroeder 1997; J. A. Crawford, Oregon State University, Corvallis, Ore., USA, unpublished

\footnotetext{
${ }^{1}$ E-mail:mike_gregg@fws.gov

${ }^{2}$ Present address: U.S. Fish and Wildlife Service, Hanford Reach National Monument, Richland, WA 99354, USA

${ }^{3}$ Present address: U.S. Department of Agriculture, National Wildlife Research Center, Fort Collins, CO 80521, USA
}

data), yet little information is available to account for the wide variation in sage-grouse renesting rates.

Protein may be important for renesting because it is one of the major nutrients in eggs (Carey 1996) and may be a greater limiting factor than energy for egg production in grouse (Moss 1972, Thomas and Popko 1981, Thomas 1982). Protein resources available for reproduction originate from the diet, whether from direct (exogenous) or stored (endogenous) sources (Beckerton and Middleton 1982, Carey 1996). Tetraonids generally do not rely entirely on stored protein reserves for reproduction (Thomas and Popko 1981; Thomas 1982, 1986; Remington and Braun 1988). Protein required for egg production by grouse also comes directly from the diet during spring (Moss 1977, Naylor and Bendell 1989, Delahay and Moss 1996). During periods when energy demands are high (e.g., reproduction), grouse depend on continuous feeding, large food intake, and high food-passage rates (Savory 1975, Thomas and Popko 1981, Thomas 1982, Beckerton and Middleton 1983). Therefore, intake of protein during spring may affect the ability of female sage-grouse to renest. Other factors including hen age (Sopuck and Zwickel 1983, Bergerud 1988), date of first nesting attempt (Grand and Flint 1996), and timing of nest loss (Seubert 1952, Gates 1962) have influenced renesting occurrence in other birds and could affect renesting by sage-grouse irrespective of protein reserves. However, these relationships are poorly understood; other than Schroeder (1997) and Connelly et 
al. (1993), no research has been conducted to identify factors that influence renesting propensity by sage-grouse.

Plasma proteins are the most readily obtainable measure of available protein in the body of birds (Amand 1986). Total plasma protein has been used as an indicator of body condition (de le Court et al. 1995, Dawson and Bortolotti 1997, Schoech and Bowman 2003) and protein available for breeding (Herbert et al. 2002, Schoech and Bowman 2003, Dunbar et al. 2005) in birds. Plasma protein values of chickens also fluctuated relative to dietary protein intake (Leveille et al. 1960, Leveille and Sauberlich 1961). We hypothesized that total plasma protein may be a good indicator of sage-grouse renesting likelihood because dietary protein can limit egg production (Breitenbach et al. 1963) and influence clutch size (Beckerton and Middleton 1982, Aboul-Ela et al. 1992) of galliformes. Our objectives were to 1) examine the relationship among total plasma protein, hen age, date of nest initiation, and age of nest at loss on renesting by greater sagegrouse; and 2) develop a predictive model of renesting likelihood to provide inference on temporal and spatial variability of sagegrouse renesting rates.

\section{Study Area}

We conducted our study at 4 sites within the Great Basin in northwestern Nevada and southeastern Oregon, USA. Sheldon National Wildlife Refuge, Nevada, and Hart Mountain National Antelope Refuge, Oregon, were administered by the U.S. Fish and Wildlife Service and encompassed 232,294 and 114,375 ha, respectively. Montana Mountains, Nevada and Beatys Butte, Oregon, were administered by the Bureau of Land Management and encompassed 170,000 and 220,301 ha, respectively. Elevation ranged from 1,200 to $2,450 \mathrm{~m}$. Annual average precipitation and average minimum and maximum temperatures ranged from 29 to $33 \mathrm{~cm}$ and $-22^{\circ}$ and $38^{\circ} \mathrm{C}$, respectively (Western Regional Climate Center 2005).

These areas were characteristic of shrub-steppe and consisted of flat sagebrush plains interrupted by rolling hills, ridges, draws, and upland meadows. Primary shrub and tree species included Wyoming big sagebrush (Artemisia tridentata wyomingensis), mountain big sagebrush ( $A$. t. vaseyana), low sagebrush ( $A$. arbuscula), bitter-brush (Purshia tridentata), western juniper (Juniper occidentalis), curl-leaf mountain-mahogany (Cercocarpus ledifolius), and aspen (Populus tremuloides). Grasses consisted largely of bluegrass (Poa spp.), bluebunch wheatgrass (Pseudoroegneria spicata), needlegrass (Stipa spp.), fescue (Festuca spp.), basin wildrye (Leymus cinereus), and bottlebrush squirreltail (Elymus elymoides). Common annual and perennial forbs included desert parsley (Lomatium spp.), mountain-dandelion (Agoseris spp.), milk-vetch (Astragalus spp.), hawksbeard (Crepis spp.), sagebrush buttercup (Ranunculus glaberrimus), buckwheat (Eriogonum spp.), lupine (Lupinus spp.), and phlox (Phlox spp.).

\section{Methods}

We captured female sage-grouse on or near leks by spotlight (Giesen et al. 1982) during March and April 1999-2004 (Byrne 2002, Davis 2002). We fitted hens with a necklace mounted 20-g radiotransmitter (Advanced Telemetry Systems, Isanti, Minnesota, USA), and we determined age from molt patterns of primaries
(Crunden 1963). Blood (1.0 ml) was extracted from the brachial vein with a 22-gauge needle and collected into Microtainer7 EDTA tubes (Becton Dickinson and Company, Franklin Lakes, New Jersey). Total plasma protein was measured by refractometer at the Veterinary Diagnostic Laboratory, College of Veterinary Medicine, Oregon State University, Corvallis, USA. Bloodcollection protocol was approved by Oregon State University Institutional Animal Care and Use Committee (Animal Care and Use Proposal Number 2656).

Beginning in mid-April, we obtained remote telemetry locations by triangulation, and we used them to monitor radiomarked hens until they dispersed from leks. Subsequently, we obtained visual locations by approaching radiomarked hens with hand-held antennas to ascertain nesting chronology. We visually confirmed incubation of hens on nests, and we recorded nest locations as Universal Transverse Mercator coordinates to facilitate location of nest sites after incubation was terminated. We did not intentionally flush hens from nests, and after incubation was confirmed, we monitored nesting hens $\geq 100 \mathrm{~m}$ from the nest site to avoid disturbance. When incubation ceased, we determined nest fate by condition of nest and eggs, and we used visual observations to confirm hens with broods. We classified nests as unsuccessful if all eggs failed to hatch because of predation or abandonment. We monitored hens with unsuccessful nests to determine renesting activities. Our goal was to monitor radiomarked hens once every 3 days to determine exact dates of nest initiation and nest loss, but distribution and movements of hens precluded frequent monitoring for all birds. Therefore, we used monitoring data from radiomarked females to classify nest initiation dates and nest age at loss for first nests into broad periods.

We used logistic regression (PROC GENMOD; SAS Institute 2001) to examine patterns in renesting occurrence with respect to date of first nest initiation, age of first nest at loss, hen age, and total plasma protein levels. We used only hens available to renest in our analysis. We censored hens that nested successfully or died during their first nesting attempt. Because nests were very difficult to locate at the initiation of egg laying, we defined nest initiation as the start of incubation. Nests lost during egg laying were not detected; consequently, we considered renests only for hens that initiated incubation of first nests. We assumed that hens captured with brood patches had initiated incubation prior to capture, and we censored them. We used the date incubation was confirmed and the last visual location that hens were not incubating to classify nest initiation dates for first nests into 3 periods (NIP): early (11-23 Apr), mid (24 Apr-3 May), and late (4-14 May). We divided the age of first nest at loss into 2 periods of incubation (IP): early (0-14 days) and late (15-28 days), based on the lastknown date hens were incubating and the date we found nests depredated or abandoned. We divided hen age (AGE) into adult (entering at least their second breeding season) or yearling (entering their first breeding season). We investigated multicollinearity by examining a correlation matrix (PROC CORR; SAS Institute 2001) and tolerances (PROC REG; SAS Institute 2001) of all predictor variables (Allison 1999).

We developed 9 a priori candidate models to explain renesting occurrence by sage-grouse based on our knowledge of reproductive ecology from previous sage-grouse research (Barnett and Craw- 


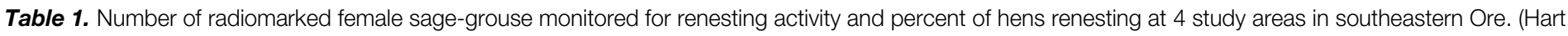
Mountain and Beatys Butte) and northwestern Nev. (Sheldon and Montana Mountains), USA, $1999-2004$.

\begin{tabular}{|c|c|c|c|c|c|c|c|c|c|c|}
\hline \multirow[b]{3}{*}{ Year } & \multicolumn{8}{|c|}{ Study areas } & & \\
\hline & \multicolumn{2}{|c|}{ Hart Mountain } & \multicolumn{2}{|c|}{ Beatys Butte } & \multicolumn{2}{|c|}{ Sheldon } & \multicolumn{2}{|c|}{ Montana Mountains } & \multicolumn{2}{|c|}{ All areas } \\
\hline & $n$ & $\%$ & $n$ & $\%$ & $n$ & $\%$ & $n$ & $\%$ & $n$ & $\%$ \\
\hline 1999 & 7 & & & & 4 & & & & 11 & 64 \\
\hline 2000 & 3 & & 5 & & 2 & & & & 10 & 30 \\
\hline 2001 & 4 & & 7 & & 5 & & & & 16 & 37 \\
\hline 2002 & 16 & & 9 & & 21 & & & & 46 & 39 \\
\hline 2003 & 17 & & 15 & & 12 & & & & 44 & 20 \\
\hline 2004 & & & & & & & 16 & & 16 & 31 \\
\hline All years & 47 & 19 & 36 & 39 & 44 & 45 & 16 & 31 & 143 & 34 \\
\hline
\end{tabular}

${ }^{a}$ Percent of hens that renested by study and year.

ford 1994, Gregg et al. 1994, DeLong et al. 1995, Coggins 1998, Byrne 2002, Davis 2002) and observations during data collection for our study. We treated AGE (yearling $=0$, adult $=1$ ) and IP $($ early $=1$, late $=0)$ as dummy variables. We treated NIP (early $=$ 1 , mid $=2$, and late $=3$ ) and total plasma protein (TPP) as quantitative variables because model fit did not improve when the linearity constraint was relaxed (Allison 1999). The global model included TPP, NIP, IP, and AGE and interactions for TPP with AGE, NIP, and IP. We used deviance ( $\hat{c}=$ goodness-of-fit $\left.x^{2} / \mathrm{df}\right)$ to determine whether the structure of the global model was appropriate for the data (Burnham and Anderson 2002). We used Akaike's Information Criterion adjusted for small sample sizes $\left(\mathrm{AIC}_{c}\right)$ and Akaike weights $\left(w_{i}\right)$ to choose the best approximating model from the group of candidate models given the data (Burnham and Anderson 2002). We ranked models based on lowest $\mathrm{AIC}_{c}$ values and calculated differences between the bestfitted model and all other models. We calculated Akaike weights from $\mathrm{AIC}_{c}$ values to provide estimates of a model's probability given other candidate models. We used Akaike weights to generate weighted parameter estimates and unconditional standard errors for all 4 predictor variables (Burnham and Anderson 2002). Model-averaged parameter estimates were not conditional on a single model and included model selection uncertainty into the final parameter estimates and standard errors. We calculated odds ratios and $95 \%$ confidence intervals (CI) from unconditional parameter estimates to evaluate the potential effect each variable had on the probability of renesting by sage-grouse (Allison 1999). We calculated maximum rescaled generalized $r^{2}$ values to estimate the precision of each model (Allison 1999).

To evaluate robustness of the predictor variables relative to considerable temporal and spatial variation in renesting rates, we did not include year and study area as covariates in candidate models. Data from 1999 to 2004 collected at all study areas were combined and used for model building. Without year and area variables in candidate models, temporal and spatial uncertainty of renesting were not included in the parameter estimates. We validated the best-fitted model, using model-averaged parameter estimates, with independent data not used for model building. We obtained independent data by randomly removing hens $(n=16)$ from the original data set before we conducted initial analysis. Because all predictor variables could potentially vary among years and study areas, model validation with independent data provided an assessment of how well the model performed without explicitly incorporating temporal and spatial variation in renesting rates. Because model selection results were dependent on the group of hens removed from the data set for validation, we conducted 100 iterations of our analysis. Data sets (model building and validation) for each iteration were created by simple random sampling without replacement (SAS Institute 2001). We averaged results from the iterations to estimate final $\mathrm{AIC}_{c}$ scores, maximum rescaled generalized $r^{2}$ values, weighted parameter estimates, and predicted probabilities of renesting.

\section{Results}

We monitored 143 radiomarked females with unsuccessful initial nests for renesting activity (Table 1 ). The earliest estimated start of incubation for first nests was 11 April and the latest was 14 May. Capture dates for hens ranged from 16 March to 27 April for all years, but $89 \%(127 / 143)$ were captured before 11 April. Depredation and abandonment accounted for $85 \%(122 / 143)$ and $15 \%(21 / 143)$ of the unsuccessful first nests, respectively. Overall, $34 \%(48 / 143)$ of the hens renested (Table 1). We found no evidence of multicollinearity among predictor variables; $r$ values and tolerances ranged from -0.09 to 0.16 and 0.96 to 0.99 , respectively. The structure of our global model was appropriate for the data $(\hat{c}=1.09)$. The best-fitted model included TPP, NIP, $\mathrm{IP}$, and AGE (Table 2). All other models were $>2 \mathrm{AIC}_{c}$ units from the best model, indicating that all 4 variables were important predictors of renesting occurrence by greater sagegrouse (Table 2).

Mean TPP $(\mathrm{g} / \mathrm{dl})$ was greater for renesting $(\bar{x}=6.4, \mathrm{SE}=0.18$, $n=48)$ than non-renesting $(\bar{x}=6.0, \mathrm{SE}=0.11, n=95)$ hens and was independent of AGE, NIP, or IP (Table 2, Fig. 1). Each 0.1 $\mathrm{g} / \mathrm{dl}$ increase in TPP was associated with a $1.55 \%$ increase in the predicted odds of renesting (Table 3). Hens that renested typically initiated first nests early in the nesting season and lost nests early during incubation (Table 4). The predicted odds of renesting decreased 1.93 times for each increase in nest initiation period (i.e., early to mid and mid to late) and was 8.53 times greater when initial nests were depredated during the first 2 weeks of incubation compared to the last 2 weeks of incubation (Table 3). Adult and yearling hens that initiated and lost first nests during early nest initiation and incubation periods contributed $52 \%(25 / 48)$ of all renests (Fig. 2). 
Table 2. Mean Akaike's Information Criteria $\left(\mathrm{AlC}_{c}\right)$ values and maximum rescaled generalized $r^{2}$ for candidate models used to examine patterns in renesting occurrence of radiomarked female greater sage-grouse $(n=143)$ in southeastern Ore. and northwestern, Nev., USA, 1999-2004. Variation in renesting was considered with respect to age (adults and yearlings), nest initiation period for first nest (nip; early=11-23 Apr, mid=24 Apr-3 May, late = 4-14 May), nest-loss period for first nests (ip; early $=0-14$ days incubation and late $=15-28$ days incubation), and total plasma protein (tpp). Total plasma protein was measured from blood samples collected at time of capture during Mar and Apr. Mean values for statistics $\left(\mathrm{AlC}_{c}, w_{i}\right.$, and $\left.r^{2}\right)$ were determined from 100 iterations of model selection using 127 hens selected with simple random sampling without replacement.

\begin{tabular}{|c|c|c|c|c|c|c|}
\hline Model & $\Delta \mathrm{AIC}_{c}$ & SE & $w_{i}^{a}$ & SE & $r^{2}$ & SE \\
\hline age + nip $+i p+t p p$ & 0.012 & 0.007 & 0.562 & 0.010 & 0.296 & 0.003 \\
\hline age + nip + ip & 2.272 & 0.136 & 0.204 & 0.010 & 0.257 & 0.003 \\
\hline nip + ip + tpp & 3.279 & 0.135 & 0.127 & 0.007 & 0.248 & 0.003 \\
\hline age + nip $+i p+t p p+t p p^{*} a g e+t p p^{*} n i p+t p p^{*} i p$ & 4.991 & 0.079 & 0.050 & 0.002 & 0.311 & 0.003 \\
\hline nip + ip & 5.049 & 0.171 & 0.056 & 0.004 & 0.213 & 0.003 \\
\hline age + tpp & 18.819 & 0.300 & 0.000 & 0.000 & 0.078 & 0.002 \\
\hline age & 20.291 & 0.313 & 0.000 & 0.000 & 0.041 & 0.001 \\
\hline tpp & 20.757 & 0.304 & 0.000 & 0.000 & 0.036 & 0.001 \\
\hline intercept only (null model) & 22.043 & 0.307 & 0.000 & 0.000 & & \\
\hline
\end{tabular}

${ }^{a}$ Akaike weight.

A greater proportion of adults than yearlings renested (Table 4). The predicted odds of adult hens renesting were 2.41 times that of yearling females (Table 3). The greatest contribution to renesting $(33 \%, 16 / 48)$ was by adult females that initiated first nests in the early nest period and lost nests early during incubation (Fig. 2). Mean TPP was similar for adults $(\bar{x}=6.1, \mathrm{SE}=0.13, n=75)$ and yearlings $(\bar{x}=6.2, \mathrm{SE}=0.13, n=68)$, but more adults $(59 \%, 44$ / 75) initiated first nests during the early nest period than yearlings $(47 \%, 32 / 68)$.

The proportion of hens renesting varied considerably among years and study areas (Table 1). Validation of the best model indicated that our predictor variables were important for distinguishing renesting status and likely explained substantial temporal and spatial variation in renesting rates. Predicted probabilities of renesting were 0.65 (95\% CI: 0.63 to 0.67$)$ for hens that renested and 0.44 (95\% CI: 0.42 to 0.46$)$ for hens that

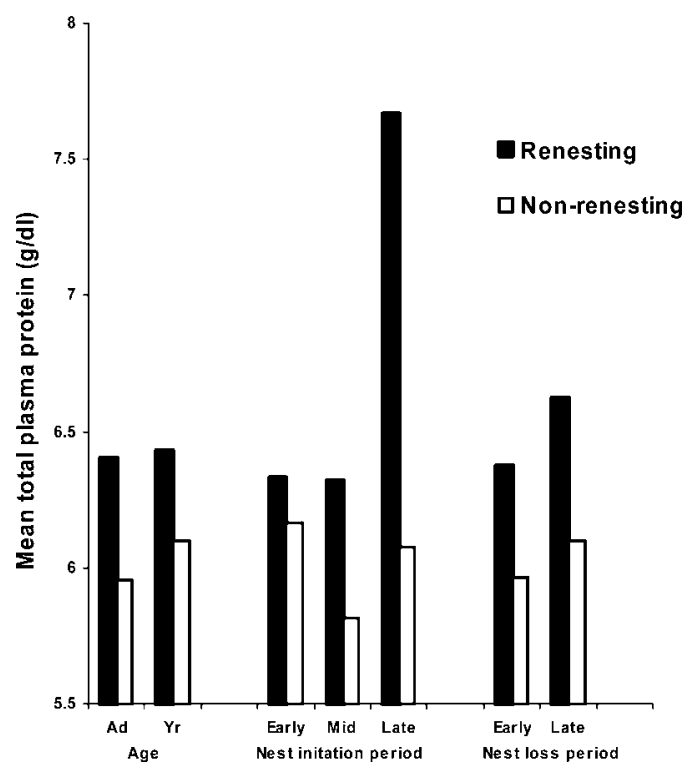

Figure 1. Mean total plasma protein values by age ( $\mathrm{Ad}=$ adult, $\mathrm{Yr}=$ yearling), nest initiation period (early $=11-23 \mathrm{Apr}$, mid $=24 \mathrm{Apr}-3$ May, and late $=4-14$ May), and nest loss period (early $=0-14$ days incubation and late $=15-28$ days incubation) for renesting $(n=48)$ and non-renesting $(n=95)$ radiomarked female greater sage-grouse in southeastern Ore. and northwestern Nev., USA, 1999-2004. did not renest. However, the best model had low predictive power for any given hen (Table 2). Predicted probability for renesting ranged from 0.18 to 0.88 and 0.26 to 0.67 for renesting and nonrenesting hens, respectively.

\section{Discussion}

Total plasma protein levels were greater for renesting compared to non-renesting hens irrespective of age or when incubation of first nests were initiated or terminated. Little research has evaluated relationships between protein levels from blood samples and reproduction in Tetraonids. Dunbar et al. (2005) reported that total plasma protein levels of prelaying, female greater sage-grouse were related to chick survival. In addition, Herbert et al. (2002) reported that plasma-amino acid concentrations were correlated with productivity of herring gulls (Larus argentatus), and Schoech and Bowman (2003) indicated that total plasma protein levels of Florida scrub-jays (Aphelocoma coerulescens) were linked to timing of reproduction.

Greater total plasma protein levels of renesting sage-grouse hens during our study may have been related to increased dietary protein intake. Female grouse typically shifted to protein-rich foods during spring (Moss 1972, Williams et al. 1980, Thomas and Popko 1981, Brittas 1988, Naylor and Bendell 1989, Barnett and Crawford 1994). Although no data were available on required levels of exogenous protein necessary for egg development by sagegrouse, Naylor and Bendell (1989) estimated that spring diets of spruce grouse (Falcipennis canadensis) provided $60 \%$ of the protein required for clutch formation. In Oregon, consumption of forbs increased protein content of diets of prelaying female greater sagegrouse, and increased forb consumption coincided with increased sage-grouse productivity (Barnett and Crawford 1994). We suggest that increased consumption of forbs by sage-grouse during spring immediately prior to reproduction provided the necessary exogenous source of protein for reproduction. Although renesting by sage-grouse during our study varied because of other factors, we surmise that inadequate protein for egg production may have accounted for some variation in renesting rates. Reduced forb availability during spring could have limited dietary protein intake and egg production, and it could have influenced the ability of sage-grouse to renest. However, the extent that protein availability limited sage-grouse renesting was unknown. 
Table 3. Mean model-averaged parameter estimates, unconditional standard errors, odds ratios, and 95\% confidence intervals for predictor variables from models used to examine patterns in renesting occurrence of radiomarked female greater sage-grouse $(n=143)$ in southeastern Ore. and northwestern, Nev., USA, 1999-2004. Predictor variables included age (adults and yearlings), nest initiation period for first nest (early = 11-23 Apr, mid = 24 Apr-3 May, late $=4-14$ May), nest loss period for first nests (early $=0-14$ days incubation, late $=15-28$ days incubation), and total plasma protein. Total plasma protein was measured from blood samples collected at time of capture during Mar and Apr. Mean values for statistics were determined from 100 iterations of model selection using 127 hens selected with simple random sampling without replacement.

\begin{tabular}{lcccc}
\hline Parameter & Estimate & SE & Odds ratio & $\mathbf{9 5 \%} \mathbf{C l}$ \\
\hline Age & 0.866 & 0.642 & 2.41 & 1.15 to 3.67 \\
Nest initiation period & -0.648 & 0.479 & 1.93 & 0.99 to 2.87 \\
Nest loss period & 2.123 & 0.694 & 8.53 & 7.17 to 9.89 \\
Total plasma protein & 0.434 & 0.269 & 1.55 & 1.02 to 2.08 \\
\hline
\end{tabular}

The extent that total plasma protein indexes dietary protein intake by sage-grouse is unknown. Total plasma protein values may be influenced by factors other than diet, particularly by hormones that are secreted as hens approach laying. During follicle development, estrogen is secreted and protein is mobilized from the liver (Lofts and Murton 1973) that may cause new protein material to appear and some existing plasma proteins to increase or decrease (Vanstone et al. 1955, Schjeide et al. 1963). Martin et al. (1981) reported that total plasma protein levels of eastern wild turkeys (Meleagris gallopavo silvestris) gradually increased during spring, and they speculated that the increase was in response to higher estrogen levels. However, Dawson and Bortolotti (1997) reported that total plasma protein values of prelaying American kestrels (Falco sparverius) increased with capture date during spring, and they suggested that the increase was a function of nutritional condition and not a response to hormonal secretion. Herbert et al. (2002) reported that plasmaamino acid concentrations of herring gulls increased in response to greater dietary protein intake. In addition, Sturkie (1954:34) reported that normal estrogen levels of laying and nonlaying chicken hens did not have an appreciable effect on total plasma

Table 4. Number of renesting and non-renesting radiomarked female sagegrouse $(n=143)$ by age, nest initiation period for first nests (early = 11-23 Apr, mid = 24 Apr-3 May, late $=4-14$ May), and nest loss period for first nests (early $=0-14$ days incubation, late $=15-28$ days incubation) in southeastern Ore. and northwestern Nev., USA, 1999-2004.

\begin{tabular}{|c|c|c|c|c|c|}
\hline \multirow[b]{3}{*}{ Variable } & \multirow{3}{*}{$\frac{\text { Hens }}{n}$} & \multicolumn{4}{|c|}{ Status } \\
\hline & & \multicolumn{2}{|c|}{ Renesting } & \multicolumn{2}{|c|}{ Non-renesting } \\
\hline & & $n$ & $\%$ & $n$ & $\%$ \\
\hline \multicolumn{6}{|l|}{ Age } \\
\hline Adult & 75 & 31 & 41 & 44 & 59 \\
\hline Yearling & 68 & 17 & 25 & 51 & 75 \\
\hline \multicolumn{6}{|c|}{ Nest initiation period } \\
\hline Early & 76 & 29 & 40 & 47 & 62 \\
\hline Mid & 48 & 16 & 33 & 32 & 67 \\
\hline Late & 19 & 3 & 16 & 16 & 84 \\
\hline \multicolumn{6}{|l|}{ Nest loss period } \\
\hline Early & 88 & 41 & 48 & 47 & 53 \\
\hline Late & 55 & 7 & 12 & 48 & 87 \\
\hline
\end{tabular}

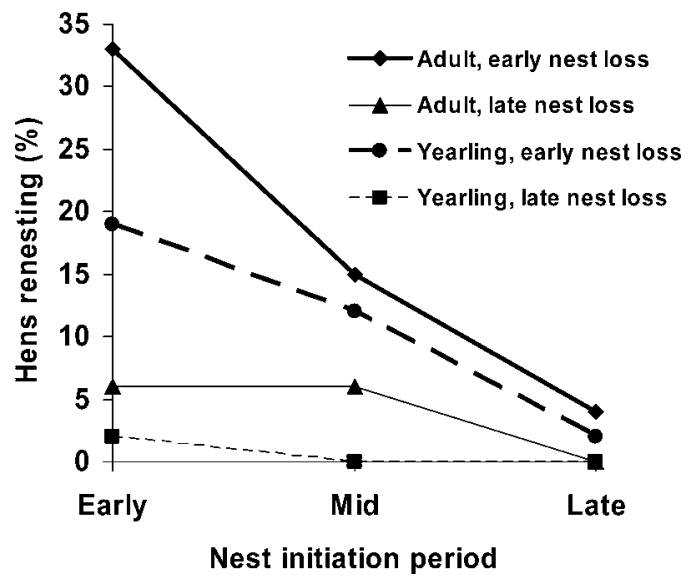

Figure 2. Contribution (\%) to overall number of renests $(n=48)$ by age, nest initiation period (early $=11-23 \mathrm{Apr}$, mid $=24 \mathrm{Apr}-3$ May, and late $=4-14$ May) and nest loss period (early $=0-14$ days incubation and late $=15-28$ days incubation) for radiomarked, female greater sage-grouse $(n=143)$ in southeastern Ore. and northwestern Nev., USA, 1999-2004.

protein values. Massive doses of estrogen were required before significant increases in total plasma protein were detected (Sturkie 1951). Total plasma protein levels of prelaying female sage-grouse also tended to increase during spring (M. A. Gregg, U.S. Fish and Wildlife Service, Lakeview, Ore., USA, unpublished data). We speculate this increase was, in part, from increased protein intake associated with greater forb consumption. However, elevated estrogen levels could also have affected total plasma protein, and additional research will be required to further elucidate relationships between hormone secretion, dietary protein, and total plasma protein levels of greater sage-grouse.

Renesting occurrence declined for hens that initiated first nests later in the nesting season or lost nests late during incubation. Schroeder (1997) reported that the number of days between start of incubation and loss of first nests tended to be greater for nonrenesting sage-grouse hens in Washington. In contrast, Sopuck and Zwickel (1983) reported that renesting by adult blue grouse (Dendragapus obscurus) was independent of nest age at time of loss. Connelly et al. (1993) suggested that renesting attempts by sagegrouse could be restricted by quality and quantity of brood-rearing habitat. Sage-grouse live in xeric environments, and survival of chicks is dependent on availability of insects and succulent vegetation (Johnson and Boyce 1990; Drut et al. 1994a,b). Optimum conditions for brood-rearing exist for a relatively short period during late spring and early summer; consequently, late renesting hens could experience high rates of brood loss (Connelly et al. 1993). The costs of late renesting may outweigh any benefits and ultimately reduce long-term fitness. The relationship we observed between renesting and date of first nest attempt also could have been influenced by hens that lost first nests during laying or early stages of incubation. We were unlikely to find nests during egg laying, and it was possible that some nests were lost very early in incubation and were not located.

Adult hens were more likely to renest than yearlings during our study. No difference in renesting rates for adult and yearling sagegrouse were found in Idaho (Connelly et al. 1993) or Washington (Schroeder 1997), but differences in monitoring techniques, sample sizes, and timing of nest loss may have accounted for 
disparities between our results and these studies. However, Bergerud (1988) indicated that adult sage-grouse hens typically renested more often than yearlings. Adult blue grouse also exhibited higher renesting rates than yearlings (Sopuck and Zwickel 1983). Adult hens may have renested more readily than yearlings during our study because they nested earlier in the nesting season. Schroeder (1997) also reported that adult sagegrouse nested earlier than yearlings in Washington. However, we found that differences in renesting rates between adults and yearlings were independent of nest initiation period for first nests. This suggested that additional factors were responsible for different renesting rates between age classes. Nutrient reserves may have accounted for differences in renesting rates of adult and yearling blue grouse (Sopuck and Zwickel 1983), but was similar in mean total plasma protein for adult and yearling sage-grouse hens during our study. Other factors that could explain differences in renesting rates between adults and yearlings include social and physiological constraints and breeding experience (Zwickel 1977; Hannon et al. 1979, 1982; Martin 1995).

We found considerable spatial and temporal variation in renesting rates during our study. Model validation indicated that total plasma protein, date of first nest attempt, age of nest at termination, and hen age were important variables for distinguishing between renesting and non-renesting sage-grouse. Variation in any one of these variables could affect renesting likelihood and, at least partially, account for the wide range of renesting rates reported for sage-grouse. The precision of our best model was relatively low, which was not surprising given that we measured total plasma protein 4 to 6 weeks before renesting and classified nest initiation dates and age of nest at loss into broad categories. In addition, precision of our model was likely reduced by other factors that we did not evaluate and could have influenced sagegrouse renesting likelihood, including the intrinsic variation among hens. However, the precision of our model was comparable to other studies that used total plasma protein to predict reproductive success of greater sage-grouse (Dunbar et al. 2005).

\section{Literature Cited}

Aboul-Ela, S., H. R. Wilson, and R. H. Harms. 1992. The effects of dietary protein level on the reproductive performance of bobwhite hens. Poultry Science 71:1196-1200.

Aldridge, C. L., and R. M. Brigham. 2001. Nesting and reproductive activities of greater sage-grouse in a declining northern fringe population. Condor 103:537-543.

Allison, P. D. 1999. Logistic regression using the SAS system: theory and application. SAS Institute, Cary, North Carolina, USA.

Amand, W. B. 1986. Avian clinical hematology and blood chemistry. Pages 264-276 in M. E. Fowler, editor. Zoo and wild animal medicine. Second edition. W. B. Saunders, Philadelphia, Pennsylvania, USA.

Barnett, J. K., and J. A. Crawford. 1994. Pre-laying nutrition of sage grouse hens in Oregon. Journal of Range Management 47:114-118.

Beckerton, P. R., and A. L. A. Middleton. 1982. Effects of dietary protein levels on ruffed grouse reproduction. Journal of Wildlife Management 46:569-579.

Beckerton, P. R., and A. L. A. Middleton. 1983. Effects of dietary protein levels on body weight, food consumption, and nitrogen balance in ruffed grouse. Condor 85:53-60.

Bergerud, A. T. 1988. Population ecology of North American grouse. Pages 578-648 in A. T. Bergerud, and M. W. Gratson, editors. Adaptive strategies and population ecology of northern grouse. University of Minnesota Press, Minneapolis, USA.

\section{Management Implications}

Habitat management for sage-grouse should include restoration of early-season forbs within degraded sagebrush stands to improve the nutritional status of hens and the potential for renesting. Important sage-grouse food forbs that should be considered for habitat restoration projects include members of Compositae, Umbelliferae, and Leguminosae families (Barnett and Crawford 1994; M. A. Gregg, U.S. Fish and Wildlife Service, Lakeview, Ore., USA, unpublished data).

Total plasma protein may be useful for evaluating reproductive potential of sage-grouse. In addition to our results, Dunbar et al. (2005) suggested that blood parameters were useful for assessing condition of greater sage-grouse and were related to reproductive success (e.g., chick survival). Additional research is required before land managers can incorporate physiological parameters into sagegrouse monitoring or conservation plans. We recommend that future research focus on the extent that sage-grouse rely on exogenous sources of protein for reproduction and relationships between total plasma protein, dietary protein, diet composition, and forage availability. Ultimately, total plasma protein may be an effective management tool to monitor sage-grouse habitat condition and the health and reproductive potential of sagegrouse populations.

\section{Acknowledgments}

This research was funded by the U.S. Fish and Wildlife Service, Bureau of Land Management, National Fish and Wildlife Foundation, Oregon Department of Fish and Wildlife, Nevada Division of Wildlife, Nevada Bighorns Unlimited, and Nevada Chukar Foundation. We acknowledge logistic and technical support provided by J. T. Forbes of the Bureau of Land Management and J. Lane of the Beatys Butte Grazing Association. We thank M. W. Byrne, M. A. Cecchini, D. M. Davis, and numerous field technicians and volunteers for assistance with data collection. J. K. Barnett, C. E. Braun, J. W. Connelly, and M. R. Ritter provided comments on earlier versions of this manuscript.

Breitenbach, R. P., C. L. Nagra, and R. K. Meyer. 1963. Effect of limited food intake on cyclic annual changes in ring-necked pheasant hens. Journal of Wildlife Management 27:24-36.

Brittas, R. 1988. Nutrition and reproduction of the willow grouse Lagopus lagopus in central Sweden. Ornis Scandinavica 19:49-57.

Burnham, K. P., and D. R. Anderson. 2002. Model selection and inference: a practical information-theoretic approach. Second edition. Springer-Verlag, New York, New York, USA.

Byrne, M. W. 2002. Habitat use by female greater sage grouse in relation to fire at Hart Mountain National Antelope Refuge, Oregon. Thesis, Oregon State University, Corvallis, USA.

Carey, C. 1996. Female reproductive energetics. Pages 324-374 in C. Carey, editor. Avian energetics and nutritional ecology. Chapman and Hall, New York, New York, USA.

Coggins, K. A. 1998. Relationship between habitat changes and productivity of sage grouse at Hart Mountain National Antelope Refuge, Oregon. Thesis, Oregon State University, Corvallis, USA.

Connelly, J. W., and C. E. Braun. 1997. Long-term changes in sage grouse Centrocercus urophasianus populations in western North America. Wildlife Biology 3:229-234.

Connelly, J. W., R. A. Fischer, A. D. Apa, K. P. Reese, and W. L. Wakkinen. 
1993. Renesting by sage grouse in southeastern Idaho. Condor 95:10411043.

Connelly, J. W., S. T. Knick, M. A. Schroeder, and S. J. Stiver. 2004. Conservation assessment of greater sage-grouse and sagebrush habitats. Western Association of Fish and Wildlife Agencies, Cheyenne, Wyoming, USA.

Connelly, J. W., W. L. Wakkinen, A. D. Apa, and K. P. Reese. 1991. Sage grouse use of nest sites in southeastern Idaho. Journal of Wildlife Management 55:521-524.

Crawford, J. A., and R. S. Lutz.1985. Sage grouse population trends in Oregon, 1941-1983. The Murrelet 66:69-74.

Crunden, C. W. 1963. Age and sex of sage grouse from wings. Journal of Wildlife Management 27:846-849.

Davis, D. M. 2002. Breeding season habitat use and response to management activities by greater sage-grouse on Sheldon National Wildlife Refuge, Nevada. Thesis, Oregon State University, Corvallis, USA.

Dawson, R. D., and G. R. Bortolotti. 1997. Total plasma protein level as an indicator of condition in wild American kestrels (Falco sparverius). Canadian Journal of Zoology 75:680-686.

de le Court, C., E. Aguilera, and F. Recio. 1995. Plasma chemistry values of free-living white spoonbills (Platalea leucorodia). Comparative Biochemical Physiology 112A:137-141.

Delahay, R. J., and R. Moss. 1996. Food intake, weight changes, and egg production in captive red grouse before and during laying: effects of the parasitic nematode Trichostrongylus tenuis. Condor 98:501-511.

DeLong, A. K., J. A. Crawford, and D. C. DeLong, Jr. 1995. Relationships between vegetational structure and predation of artificial sage grouse nests. Journal of Wildlife Management 59:88-92.

Drut, M. S., J. A. Crawford, and M. A. Gregg. 1994a. Brood habitat use by sage grouse in Oregon. Great Basin Naturalist 54:170-176.

Drut, M. S., W. H. Pyle, and J. A. Crawford. 1994b. Diets and food selection of sage grouse chicks in Oregon. Journal of Range Management 47:90-93.

Dunbar, M. A., M. A. Gregg, J. A. Crawford, M. R. Giordano, and S. J. Tornquist. 2005. Normal hematologic and biochemical values for pre-laying greater sage-grouse (Centrocercus urophasianus) and their influence on chick survival. Journal of Zoo and Wildlife Medicine 36:71-78.

Gates, J. M. 1962. Breeding biology of the gadwall in northern Utah. Wilson Bulletin 74:43-67.

Giesen, K. M., T. J. Schoenberg, and C. E. Braun. 1982. Methods for trapping sage grouse in Colorado. Wildlife Society Bulletin 10:224-231.

Grand, J. B., and P. F. Flint. 1996. Renesting ecology of northern pintails on the Yukon-Kuskokwim delta, Alaska. Condor 98:820-824.

Gregg, M. A., J. A. Crawford, M. S. Drut, and A. K. DeLong. 1994. Vegetational cover and predation of sage grouse nests in Oregon. Journal of Wildlife Management 58:162-166.

Hanf, J. M., P. A. Schmidt, and E. B. Groshens. 1994. Sage grouse in the high desert of central Oregon: results of a study, 1988-1993. U.S. Department of the Interior, Bureau of Land Management, Prineville District Office, Series PSG-01.

Hannon, S. J., B. R. Simard, F. C. Zwickel, and J. F. Bendell. 1979. Differences in the gonadal cycles of adult and yearling blue grouse. Canadian Journal of Zoology 57:1283-1289.

Hannon, S. J., L. G. Sopuck, and F. C. Zwickel. 1982. Spring movements of female blue grouse: evidence for socially induced delayed breeding in yearlings. Auk 99:687-694

Herbert, C. E., J. Laird Shutt, and R. O. Ball. 2002. Plasma amino acid concentrations as an indicator of protein availability to breeding herring gulls (Larus argentatus). Auk 119:185-200.

Johnson, G. D., and M. S. Boyce. 1990. Feeding trials with insects in the diet of sage grouse chicks. Journal of Wildlife Management 54:89-91.

Leveille, G. A., A. S. Feigenbaum, and H. Fisher. 1960. The effect of dietary protein, fat and cholesterol on plasma cholesterol and serum protein components of the growing chick. Archives of Biochemistry and Biophysics 86:67-70.

Leveille, G. A., and H. E. Sauberlich. 1961. Influence of dietary protein level on serum protein components and cholesterol in the growing chick. Journal of Nutrition 74:500-504.
Lofts, B., and R. K. Murton. 1973. Reproduction in birds. Pages 1-107 in D. S. Farner, and J. R. King, editors. Avian biology. Volume 3. Academic Press, New York, New York, USA.

Martin, K. 1995. Patterns and mechanisms for age-dependent reproduction and survival in birds. American Zoologist 35:340-348.

Martin, R. M., M. E. Lisano, and J. E. Kennamer. 1981. Plasma estrogens, total protein, and cholesterol in female eastern wild turkey. Journal of Wildlife Management 45:798-802.

Moss, R. 1972. Food selection by red grouse (Lagopus lagopus scoticus (Lath.)) in relation to chemical composition. Journal of Animal Ecology 41: 411-428.

Moss, R. 1977. The digestion of heather by red grouse during the spring. Condor 79:471-477.

Naylor, B. J., and J. F. Bendell. 1989. Clutch size and egg size of spruce grouse in relation to spring diet, food supply, and endogenous reserves. Canadian Journal of Zoology 67:969-980.

Remington, T. E., and C. E. Braun. 1988. Carcass composition and energy reserves of sage grouse during winter. Condor 90:15-19.

SAS Institute. 2001. SAS/STAT software: changes and enhancements through release 8.2. SAS Institute, Cary, North Carolina, USA.

Savory, C. J. 1975. Seasonal variations in the food intake of captive red grouse. British Poultry Science 16:471-479.

Schjeide, O. A., M. Wilkens, R. G. McCandless, R. Munn, M. Peterson, and E. Carlsen. 1963. Liver synthesis, plasma transport, and structural alterations accompanying passage of yolk proteins. American Zoologist 3:167-184.

Schoech, S. T., and R. Bowman. 2003. Does differential access to protein influence differences in timing of breeding of Florida scrub-jays (Aphelocoma coerulescens) in suburban and wildland habitats? Auk 120:1114-1127.

Schroeder, M. A. 1997. Unusually high reproductive effort by sage grouse in a fragmented habitat in north-central Washington. Condor 99:933-941.

Seubert, J. L. 1952. Observations on the renesting behavior of the ringnecked pheasant. Transactions of the North American Wildlife Conference 17:305-327.

Sopuck, L. G., and F. C. Zwickel. 1983. Renesting in adult and yearling blue grouse. Canadian Journal of Zoology 61:289-291.

Sturkie, P. D. 1951. The effects of estrogen and thyroxine upon plasma proteins and blood volume in the fowl. Endocrinology 49:565.

Sturkie, P. D. 1954. Avian physiology. Comstock, Ithaca, New York, USA.

Sveum, C. M., W. D. Edge, and J. A. Crawford. 1998a. Nesting habitat selection by sage grouse in south-central Washington. Journal of Range Management 51:265-269.

Sveum, C. M., J. A. Crawford, and W. D. Edge. 1998b. Use and selection of brood-rearing habitat by sage grouse in south-central Washington. Great Basin Naturalist 58:344-351.

Thomas, V. G. 1982. Energetic reserves of Hudson Bay willow ptarmigan during winter and spring. Canadian Journal of Zoology 60:1618-1623.

Thomas, V. G. 1986. Body condition, ovarian hierarchies, and their relation to egg formation in Anseriform and Galliform species. Proceedings of the International Ornithological Congress 19:353-363.

Thomas, V. G., and R. Popko. 1981. Fat and protein reserves of wintering and prebreeding rock ptarmigan from south Hudson Bay. Canadian Journal of Zoology 59:1205-1211.

Vanstone, W. E., W. A. Maw, and R. H. Common. 1955. Levels and partition of the fowl's serum proteins in relation to age and egg production. Canadian Journal of Biochemistry and Physiology 33:891-903.

Wallestad, R., and D. Pyrah. 1974. Movements and nesting of sage grouse hens in central Montana. Journal of Wildlife Management 38:630-633.

Western Regional Climate Center. 2005. Historical climate information. Western U.S. historical summaries (individual stations), Hart Mountain Refuge, Oregon; Sheldon, Nevada; Kings River Valley, Nevada. <http:// www.wrcc.dri.edu>. Accessed 2005 Apr 17.

Williams, J. B., D. Best, and C. Warford. 1980. Foraging ecology of ptarmigan at Meade River, Alaska. Wilson Bulletin 92:341-351.

Zwickel, F. C. 1977. Local variations in the time of breeding of female blue grouse. Condor 79:185-191.

Associate Editor: Schmutz. 